\title{
鍛造用金型の損傷評価技術に関する研究
}

\author{
岡島㛹磨 ${ }^{* 1}$, 吉田広明 $* 2$, 五十川幸宏 $* 2$
}

\section{Development of Die Life Evaluation Method on Forging}

\author{
Takuma Okajima, Hiroaki Yoshida, and Sachihiro Isogawa
}

\section{Synopsis}

Recently, warm forging process takes the place of hot forging process gradually, for example, in manufacturing CVJ. However, die damage is serious problem in warm forging process with large expansion of surface of work piece, because it is not inquired enough. Though trying to extend die life by means of FEM analysis, it dose not play an enough role, because there is few method to evaluate die damage in warm forging condition. The test of Pin-on-disk and Ogoshi wear out can not be also applied to the method of die damage of warm forging process.

In this study, we have established new test which could systematically evaluate die damage in warm forging process. And we have examined forging condition in warm forging process about quality of die and cooling system of die. This test aims at utilizing for establishment of simulation engineering of die damage prediction and quantitative evaluation method.

\section{1 . 緒 言}

鍛造加工における精密化指向は,年々高まりを見せてお り,コストダウンとともに今後の長期的なトレンドとなる ものと考えられる.この流れの中で, 熱間鍛造から温間鍛 造への転換がゆっくりと進んでおり，等速ジョイントやべ ベルギアでは , 温間鍛造化が浸透しつつある .この温間鉎 造は，熱間鍛造よりも寸法精度に優れることに加え，低温 オーステナイト域て鍛造することによって，微細で延性に 富んだフェライト・パーライト組織を得ることができ,鍛 造後の焼なましなどの省略が可能となる特徵を有してい る.

温間鍛造における最大の問題は型材の材料特性から期 待される金型寿命が実際の金型において得られていない ことである . 光の理由として, 温間鍛造の歴史か熱間鍛造 や冷間鍛造に比へて浅いために,金型損傷のメカニズムが ほとんど解明されていないことが挙げられる.実際，温間 鍛造の型設計においては, 温間鍛造に特有の現象を十分理 解した上での型設計がなされているとはいい難く,金型の 強度を重視した冷間鍛造と金型の高温化対策を重視した
熱間鍛造の設計思想か洨錯しているのか現状である 近年， FEM 解析を用いたシミュレーション技術による金型寿命 改善の取組もなされるようになってきたが,温間鍛造のシ ミュレーションに必要なデータベースが未整備であり，ま た ,シミュレーションによる予測結果を確認するための有 効な評価試験もほとんど無いのか現状である ${ }^{1) 〜 6) . ~}$

乥こで本研究では,温間鍛造における金型損傷を系統的 に評価できる試験方法を新たに構築し,温間鍛造に最適の 型材, 鍛造条件に関する検討を行った . 本評価技術は, 最 終的には,金型損傷予測シミュレーション技術の構築のた めの活用を目的とし, 定量的な評価が可能となる評価手法 の基礎技術となるものである .

\section{2 . 実験方法}

\section{1 試験方法}

本評価試験では,多段工程の温間鍛造を想定して ,Fig.1 に示す大同機械製 NS5-10PL パーツフォーマーによる2工 程鍛造を行った . パンチ材料にはマトリックスハイス鋼 MH85(0.6C-4.5Cr-3.8Mo-1.5W-1V) と MH86(0.6C-4.2Cr4.8Mo-2.5W-1V)，さらに熱間工具鋼 SKD61 の改良鋼であ 
る SKD61* (0.4C-5Cr-1.5Mo-1V) と DH71(0.4C-1Mn-2Mo$1 \mathrm{~V})$ の 4 種類を用意し，型材の違いによる損傷レベルの相 違を比較できるようにした これらの供試材の調質条件と ヴィッカース硬さを Table 1 に示す .ワーク材料には S53C を用い，加熱温度 $1093 \mathrm{~K}$, 鍛造速度 $85 \mathrm{spm}$ とした . 潤滑 剂は硫黄系添加剂を $20 \%$ 含有した粘度 $135 \mathrm{~mm}^{2} / \mathrm{s}$ の鍛造 用潤滑油を用い, 流量 $4.4 \mathrm{~L} / \mathrm{min}$ で銅パイプ 4 本を用いて パンチのテーパー部から先端にかけて吹きかけられるよ うにした この潤滑剂は鍛造時に加熱されたパンチ表面を 冷却する役割も持っている.本試験は 100 ショットごとに 鍛造材をピックアップしながら 4000 ショット行った . 試 験後, 500 ショットまでは 100 ショットごとに，乥れ以降 は 1000 ショットごとに鍛造材へシリコーン樹脂埋めを行 い,型取りしたパンチ形状のプロファイルから鍛造ショッ 卜数の増加に伴うパンチ先端 $\mathrm{R}$ 部とテーパー部の摩耗量

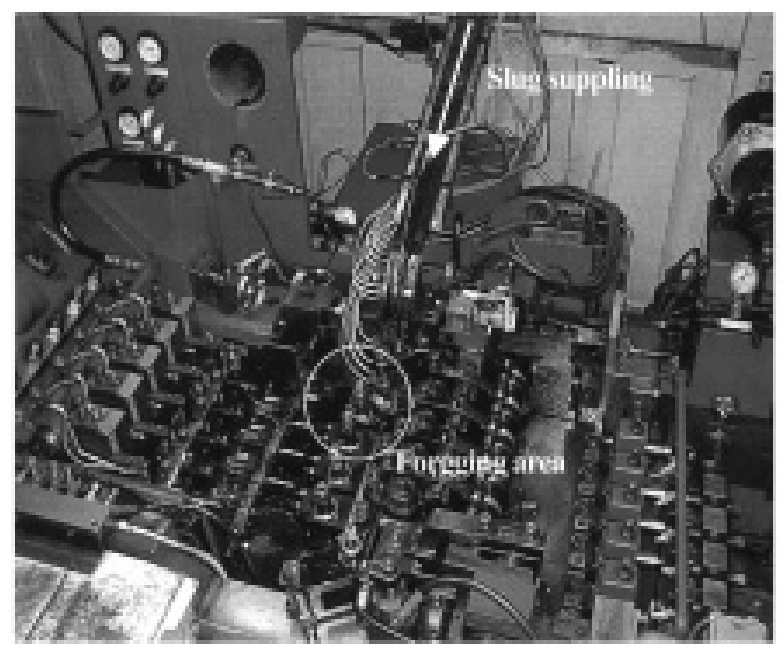

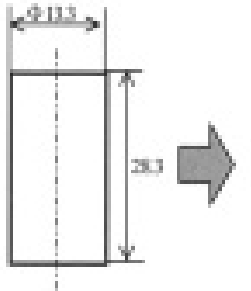

Slug

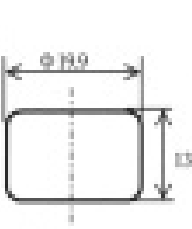

Ist Process

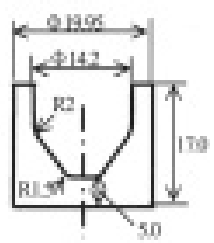

2nd Process
Fig.1. Parts former and forging process.
の測定を行った .ここで,樹脂の収縮率による補正も行っ ている.さらに ,パンチの先端部からテーパー部にわたり 長手方向に切断したものを鏡面研磨の後にナイタール(エ チルアルコール $+10 \%$ 硝酸) にて腐食し, 腐食面を光学 顕微鏡にて, 鍛造により発生したヒートチェック, 塑性流 動の状態に注目して観察した .

\section{3. 結果と考察}

\section{1 評価材の基礎特性}

鍛造金型の損傷評価を行うためには, 金型材質の基礎特 性を把握することが必要である.特に, 鍛造時の温度を反 映した評価材の高温強度は鍛造金型損傷評価を行う上で 最も重要である .

そこで,今回使用する金型供試材の高温圧縮降伏強度を Fig.2 に示す. 高温圧縮降伏強度は, $\varphi 15 \times 22.5 \mathrm{~mm}$ の端 面拘束圧縮試験片を作製し，熱間加工シミュレータを用い て各測定温度で $60 \mathrm{~s}$ 保持した後に端面拘束圧縮を行い, 光 の変形抵抗データから求めた .これによると, 全試験温度 域に渡って，マトリックスハイス鋼である MH85，MH86 の方が, 熱間ダイス鋼である SKD61*や DH71 よりも高 強度であることがわかる .MH86 は MH85 に対してほぼ全 温度域で高強度であり, 軟化抵抗が大きいといえる．方, DH71 は SKD61*に対して, 常温〜 $473 \mathrm{~K}$ までは若干

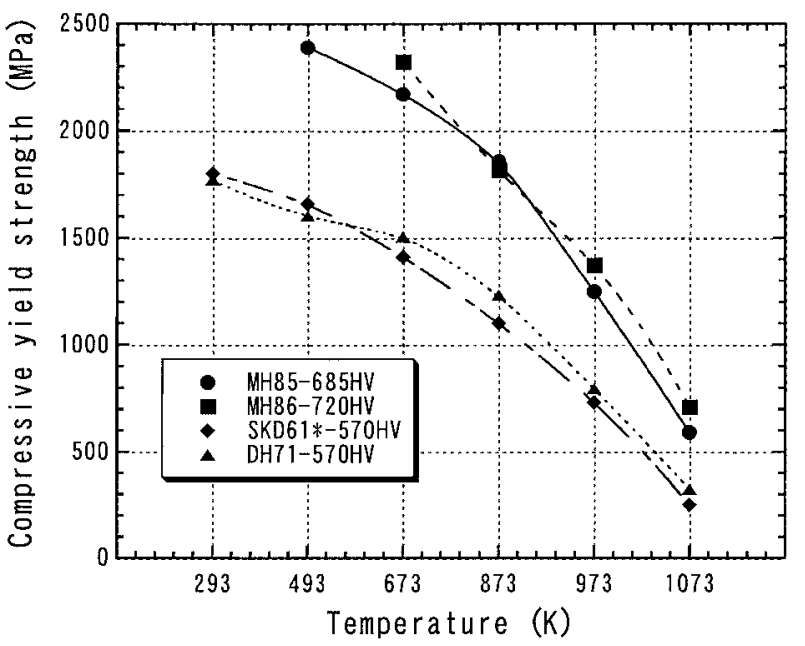

Fig.2. Compressive yield strength of test steel in high temperature.

Table 1. Hardening and tempering pattern of test pieces.

\begin{tabular}{c|c|c|c}
\hline Steel name & Hardning temperature and cooling & Tempering temperature and coolong & Vickers hardness (HV) \\
\hline MH85 & $1423 \mathrm{~K} \times 2.1 \mathrm{ks} \rightarrow \mathrm{GC}$ & $823 \mathrm{~K} \times 18 \mathrm{ks} \rightarrow \mathrm{AC}(\times 3)$ & 685 \\
\hline MH86 & $1433 \mathrm{~K} \times 180 \mathrm{~s} \rightarrow \mathrm{BC}$ & $873 \mathrm{~K} \times 3.6 \mathrm{ks} \rightarrow \mathrm{BC}(\times 2)$ & 520 \\
\hline SKD61* & $1313 \mathrm{~K} \times 180 \mathrm{~s} \rightarrow \mathrm{BC}$ & $833 \mathrm{~K} \times 3.6 \mathrm{ks} \rightarrow \mathrm{BC}(\times 2)$ & 570 \\
\hline $\mathrm{DH} 71$ & $1313 \mathrm{~K} \times 180 \mathrm{~s} \rightarrow \mathrm{BC}$ & $833 \mathrm{~K} \times 3.6 \mathrm{ks} \rightarrow \mathrm{BC}(\times 2)$ & \\
\hline
\end{tabular}


低強度であるが， $673 \mathrm{~K}$ 以上でこの関係は逆転し，DH71 の方が高い高温強度を示すことが確認された 。

これらの高温強度の異なるパンチ材料で試験すること により,温間鍛造条件下において, 高温強度が金型損傷に 及ぼす影響を系統的に調査することが可能となる．

\section{2 実験結果}

Fig.3 に試験後のパンチ外観を，Fig.4 にパンチの先端部 (Part C) , R 部 (Part R) , テーパー部 (Part T) の切断面観察 写真を示す . 全ての金型において , パンチ $\mathrm{R}$ 部からテー パー部において摩耗が進行していることがわかる．ママト リックスハイス鋼であるMH85，MH86 と比較して熱間名

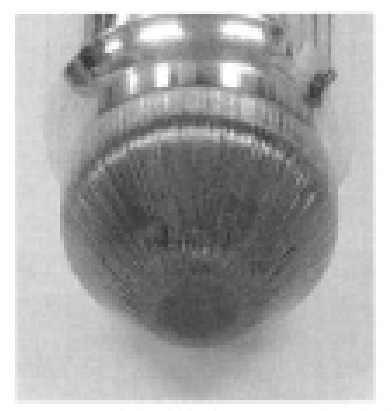

MH85

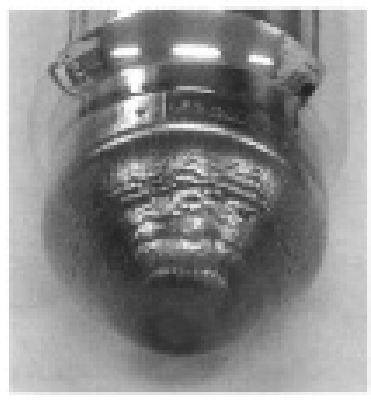

SKD61*

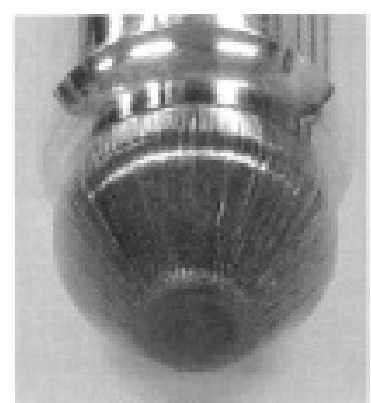

MH86

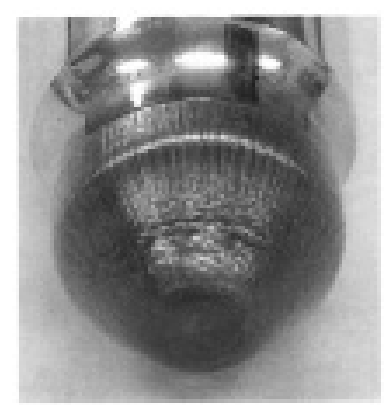

DH71
Fig.3. Photographs of external punch after test.
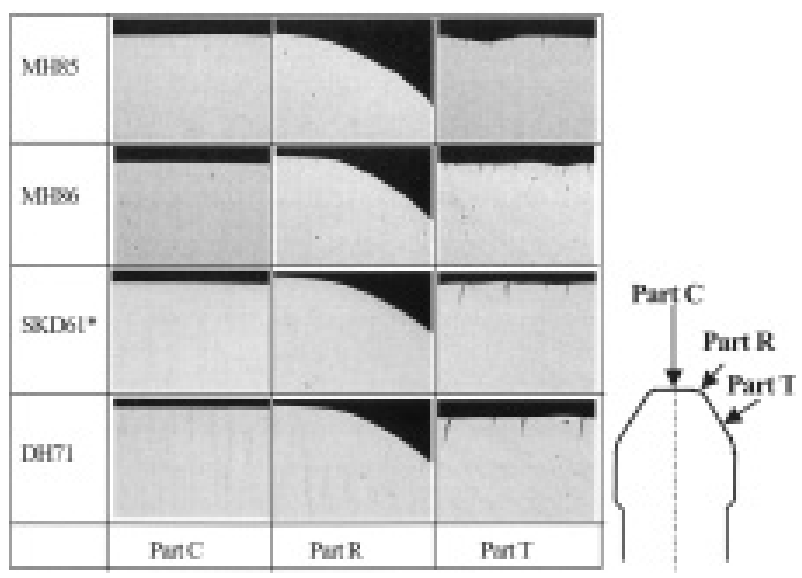

Fig.4. Micro photograph in punch point after test.
イス鋼である SKD61 *およびDH71 はテーパー部の表層 付近でヒートチェックの方向が鍛造方向に沿って湾曲し ていることから塑性流動が大きく発生し摩耗が進行して いることが確認された . また同時に ,ヒートチェックの本 数は,SKD61*およびDH71 において相対的に少ないもの の1つ1つの亀裂が深く進展していることも確認された . この損傷状況は，実機鍛造パンチによく一致したものであ り，この試験方法が温間鍛造用金型の鍛造条件をよく再現 できたものと考えられる .

Fig.5にSKD61 * と MH85 の試験終了後のパンチ縦断面 におけるヴィッカース硬さ分布を示す．双方ともに ,パン チ $\mathrm{R}$ 部, テーパー部において, 表層から $0.5 \mathrm{~mm}$ 程度の深 さまで, 初期硬さに対して軟化していることが確認され た これは鍛造時にパンチがワークと接触する時に伝達す る熱や摩擦による発熱により，パンチ表層が高温化し，こ

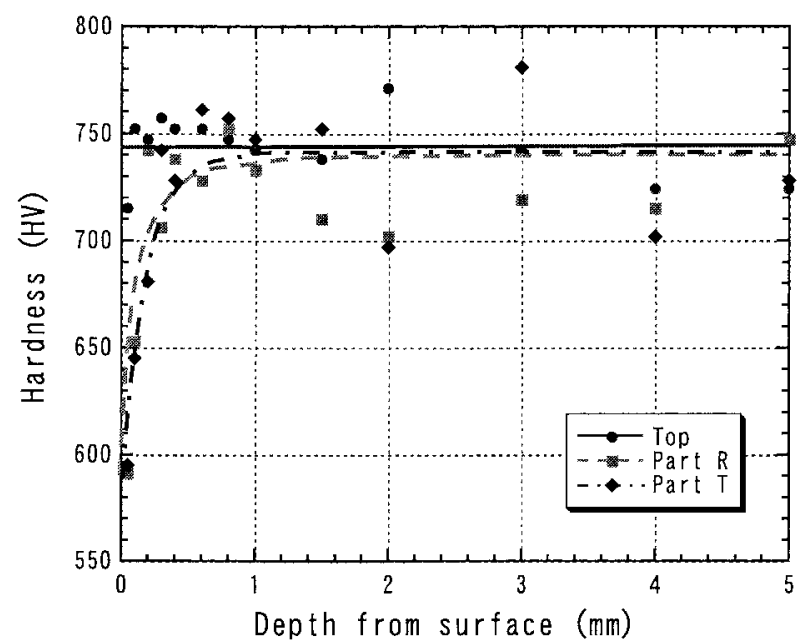

MH85

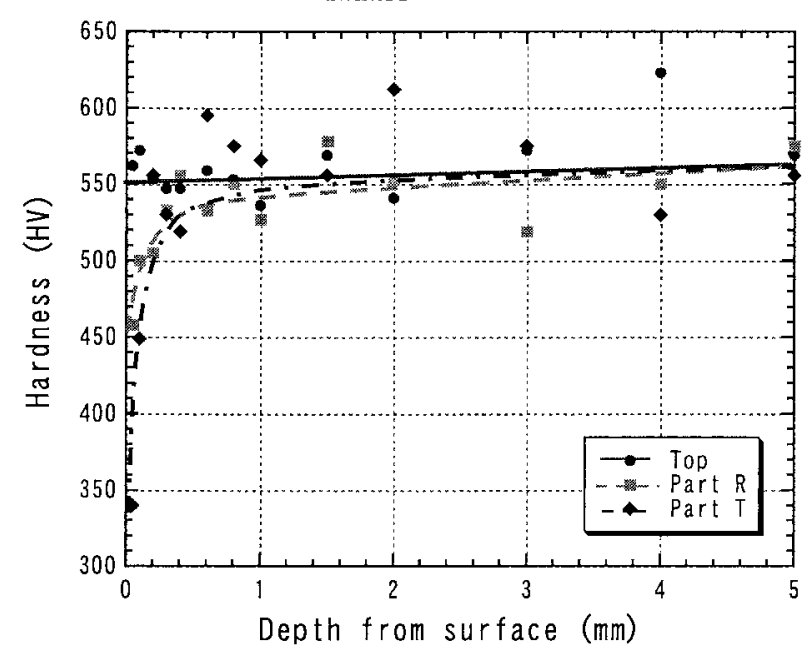

SKD61*

Fig.5. Distribution of hardness in punch. 
の状態が長時間保持されたために，初期硬さよりも軟化し たものと考えられる . また , パンチ TOP 部においては， この軟化挙動がほとんど確認されなかった．軟化挙動が発 生した部位は, 摩耗や塑性流動が発生した部位と良く一致 していることから , パンチの R 部やテーパー部で, 最も 過酷なワークの変形の作用を受けているものと推測され る。

Fig.6 にMH85 と SKD61* のワーク転写部におけるパン チ $\mathrm{R}$ 部およびテーパー部の摩耗量の推移を示す . パンチ $\mathrm{R}$ 部，テーパー部ともに，SKD61*の方が摩耗を開始する ショット数が早く,摩耗量も大きいことが確認された .ま た， 4000 ショット終了時の先端 $\mathrm{R}$ 部摩耗量の 4 鋼種別比 較を Fig.7 に示す .この結果から，SKD61*およびDH71 よりも，MH85，MH86 の方が，摩耗量が小さく金型損傷 レベルが優れていることがわかる．また，MH85 よりも MH86 の方がより優れていることがわかる .

これらの結果より，SKD61*およびDH71は，MH85や MH86 よりも軟化抵抗が小さいために，摩耗量，塑性流 動 ,ヒートチェック深さともに大きくなり，金型損傷レベ

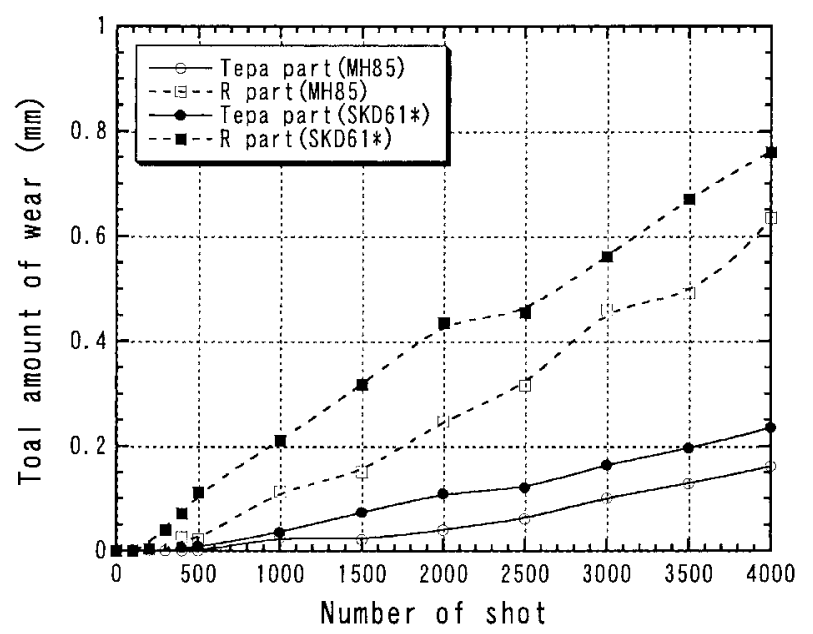

Fig.6. Wear-out transition of punch in work transcript part(MH85, SKD61-modify).
ルが大きくなつたと考えられる．また，MH86 は，MH85 に対して $873 \mathrm{~K}$ 以上で高温降伏強度が大きく，光の結果， 摩耗量が最も小さくなったと考えられる.温間鍛造に最 適な型材は, 摩耗量の定量的な測定から, 高温降伏強度と 軟化抵抗に優れた MH86 であると本試験法の結果から結 論づけることができる .

以上より,本試験法は, 温間鍛造におけるパンチ金型材 の摩耗や塑性流動といった主要な損傷を良く再現するこ とが可能であり，金型材の材質による損傷の差異を明確に し,摩耗量の測定から定量的に金型損傷を評価することの できる試験法であることが示された .

\section{4 . パンチ冷却方法の検討}

これまでの試験において,パンチへの潤滑油の吹き付け は 4 方向から銅パイプ式ノズルを用いてきた.しかしなが ら,同冷却方法では試験後のパンチ表面部位による摩耗量 や塑性流動,ヒートチェックといった損傷度合いのむらや パンチ温度を下げる冷却能力の向上が見込めないことが 問題となっていた .乥こで, これらの問題を改善するため に, Fig.8に示すようなパンチ冷却方法の変更を行った .

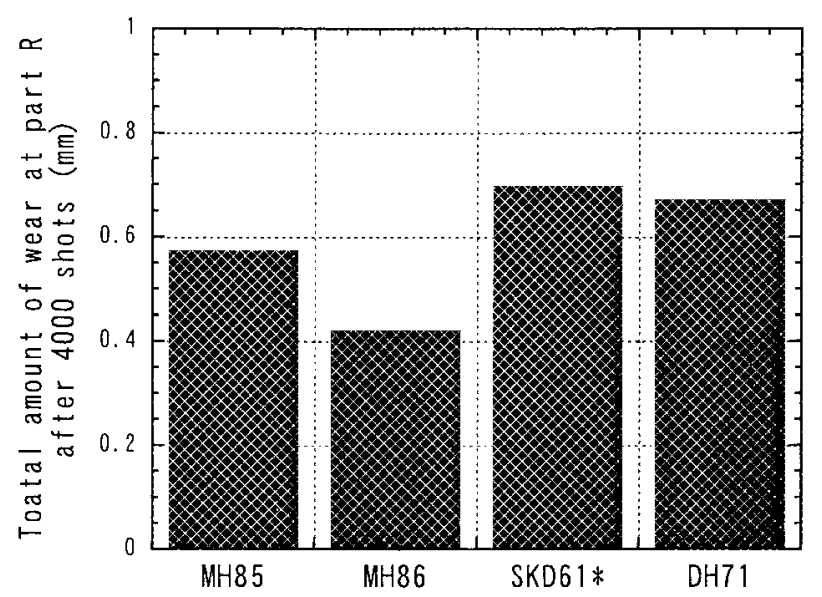

Fig.7. Amount of wear-out in point $R$ part after 4000 shots.

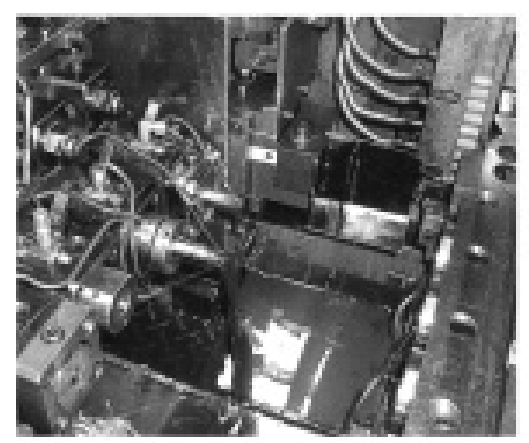

Cupper pipe cooling system

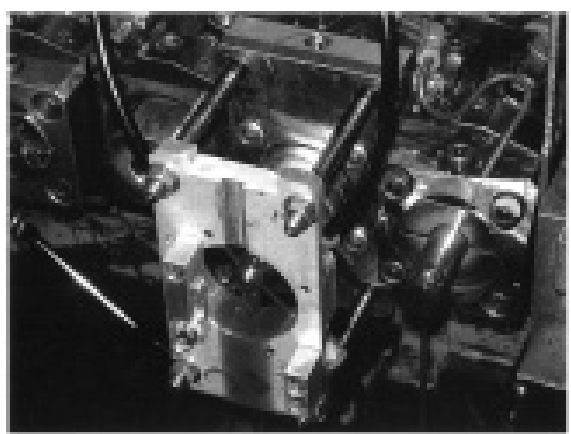

Jackes type slide cooling system

Fig.8. Comparative picture of cooling system of examination machine. 

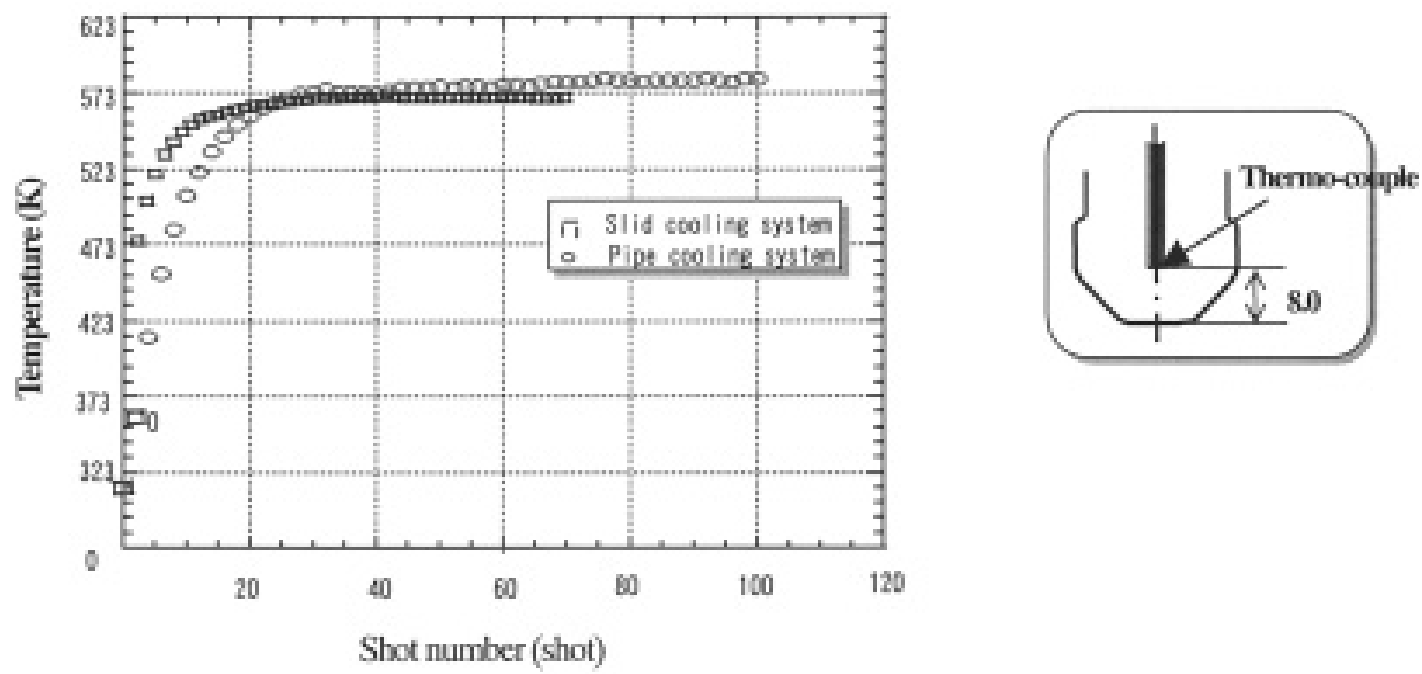

Fig.9. Punch temperature measurement result by difference of cooling system.

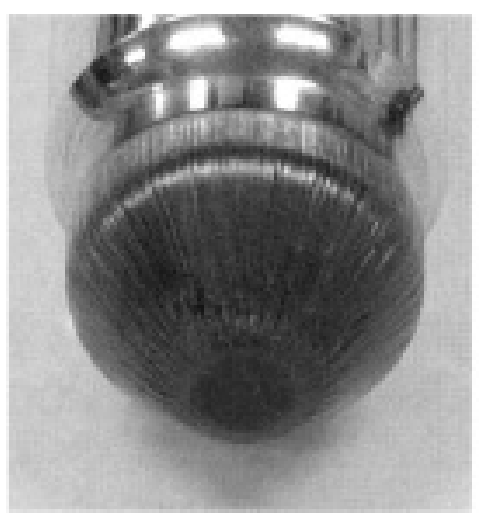

Pipe cooling system

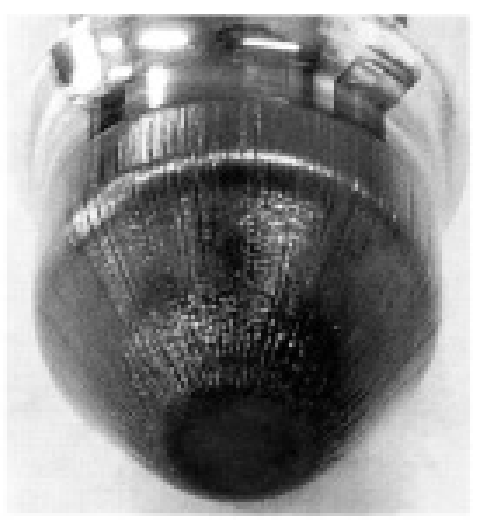

Jacket type slide cooling system

Fig.10. Punch externals photograph after 4000 shots by difference of cooling system.

これはパンチの周囲にスライド式ジャケット型の専用冶 具を取りつけ ,バネ仕掛けにより鍛造中のパンチの動きに 合わせて常に4方向から一定量の潤滑油を吹き付けること を可能にしたものである.この結果 ,パンチ温度を下げる 冷却能力を向上させ 潤滑剤を均一に吹き付けることで閏 滑・冷却むらを低減し，より再現性の高い定量的な評価試 験を実施することが可能となった .

本研究では, パンチに MH85 を用いて冷却方法による パンチの温度，摩耗の相違を調査した、鍛造条件は, 前述 2.1 で示したものと同一である. また FEM 解析によって， 鍛造工程中のパンチの温度分布を求め，冷却方法改善によ る冷却効果の比較を行った .

Fig.9 にMH85 のパンチで行った試験後の冷却方法の相
違によるパンチ温度の測定結果を示す .この図からわかる ように,定常状態でジャケット型の冷却方法の方が, 従来 の銅パイプ式のノズル型よりも約 $30 \mathrm{~K}$ パンチ温度が低下 したことから，冷却能力が向上したことが確認された .

Fig.10に 4000 ショット鍛造後のパンチ外観を, Fig.11 に乥のパンチの切断ミクロ観察写真を示す .これらの写真 より，冷却方法をジャケット型に変更することにより，パ ンチ表面のヒートチェック, 塑性流動などの損傷が, 部位 によってバラツキが生じることがなく均一になることが 確認された . また , ジャケット型においてテーパー面に ヒートチェックが多く発生しているのは, 冷却能力の向上 により,パンチ表面の温度振幅が大きくなった結果である と考えられる。 


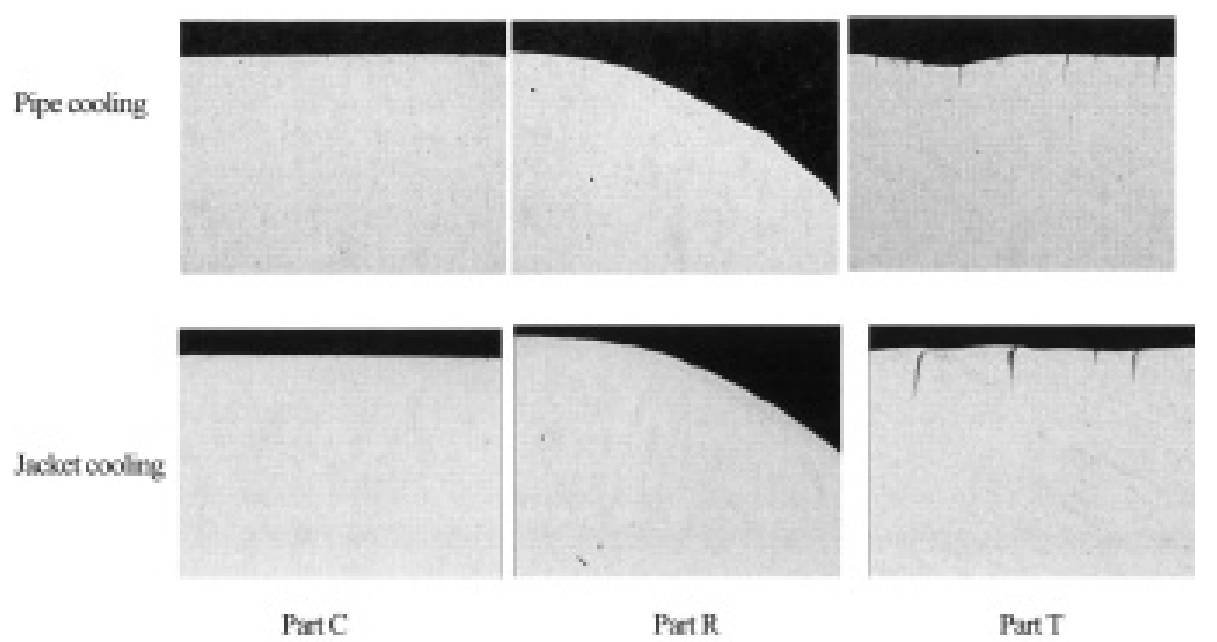

Fig.11. Micro photograph in punch point after 4000 shots by difference of cooling system.

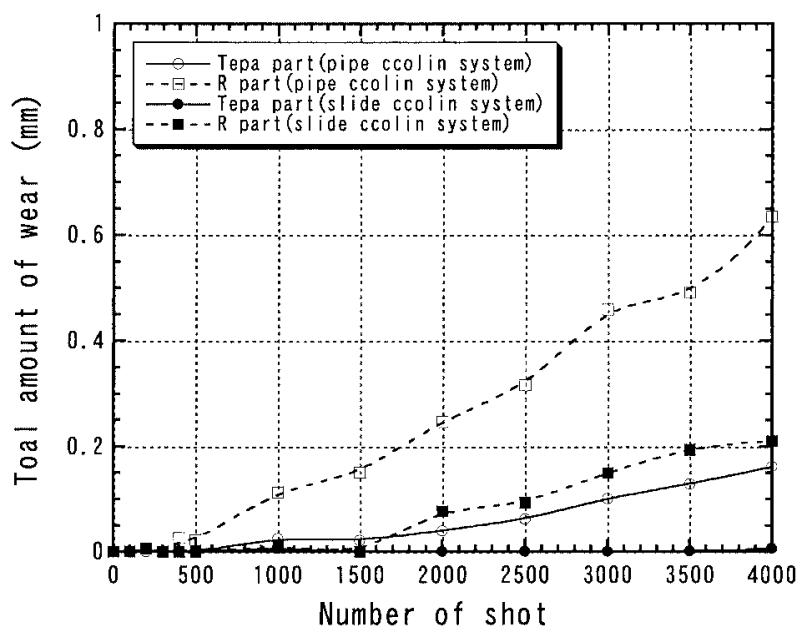

Fig.12. Transition of amount of wear-out by difference of cooling method.

Fig.12 に冷却方法の相違によるショット数とパンチ摩 耗量の推移を示す .この图からわかるように，冷却方法を ジャケット型にすることによって , パンチ先端 $\mathrm{R}$ 部では 摩耗開始ショット数はおよ光 3 倍, 摩耗量はおよ光 $1 / 3$ と なり，テーパー部ではほとんど磨耗しないことがわかっ た．また，Fig.13に 4000 ショット鍛造後の冷却方法相違 によるパンチ先端 R 部の摩耗量の比較を示す . この結果， ジャケット型の冷却方法では, 最終的な摩耗量は従来の銅 パイプ式に比べて $64 \%$ も低減することがわかった .

Fig.14 にパンチ冷却方法の相違による鍛造工程中のパ ンチ温度分布の変化をFEM解析》で計算した結果を示す． この解析は，MSC 社の Superform2004 を用い，応力・熱 練成弾塑性解析 (軸対称モデル) で行った .パンチ材質は MH85 ,ワーク材質はS53C のデータベースを用いた .ワー

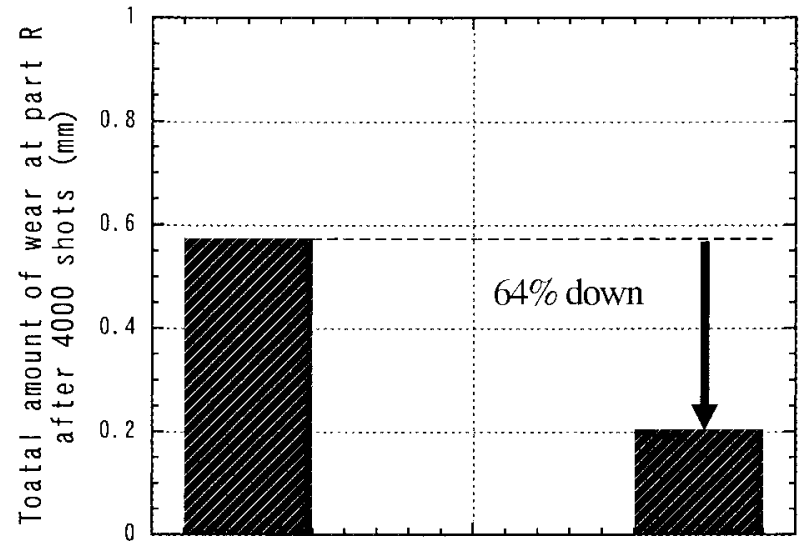

Fig.13. Amount of wear-out in point R part after 4000 shots by difference of cooling method.

クの初期温度は $1093 \mathrm{~K}$, ワークとパンチの接触熱コンダ クタンスは $120 \mathrm{~kW} / \mathrm{m}^{2} \mathrm{~K}$,せん断摩擦係数は 0.4 とした .ま た，冷却時の接触熱コンダクタンスは銅パイプ式で 6.3 $\mathrm{kW} / \mathrm{m}^{2} \mathrm{~K}$ ，ジャケット型で $9.5 \mathrm{~kW} / \mathrm{m}^{2} \mathrm{~K}$ とした .この FEM 解析の結果，鍛造中の下死点においてパンチの温度は, 銅 パイプ式ノズル型冷却法では最高温度部位 $1003 \mathrm{~K}$ まで到 達するが , ジャケット型の冷却法では $973 \mathrm{~K}$ であった .さ らに,油冷終了後は, 銅パイプ式ノズル型冷却法では最高 温度部位 $687 \mathrm{~K}$ であるのに対し, ジャケット型の冷却法で は $625 \mathrm{~K}$ となった .このことから , ジャケット型冷却法に よる冷却能力の向上の結果, パンチの最高温度を従来の銅 パイプ式ノズル冷却法よりも $30 \mathrm{~K}$ 低下させることができ， 弚れによってパンチの温度上昇による降伏強度の低下の 抑制および軟化を低減することから，パンチの摩耗を低減 させることができたと考えることができる .一方 鍛造時の 


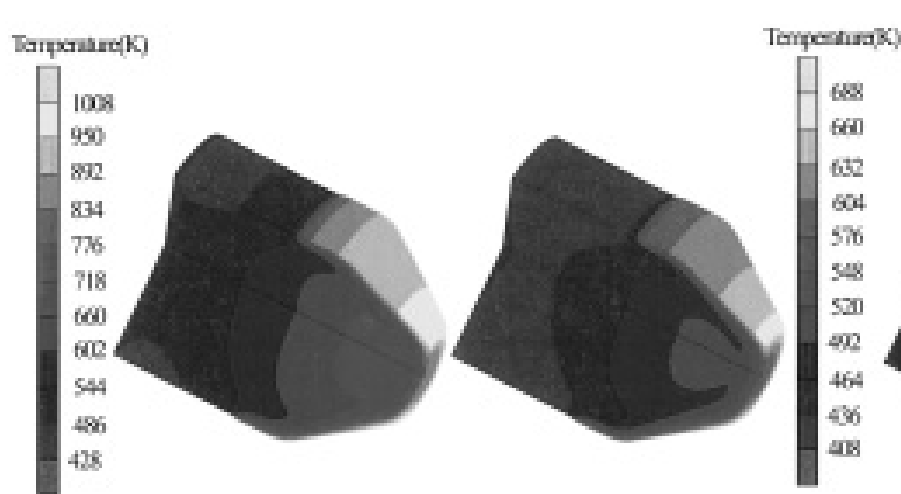

Pipe cooling system Jacket cooling system At dead point
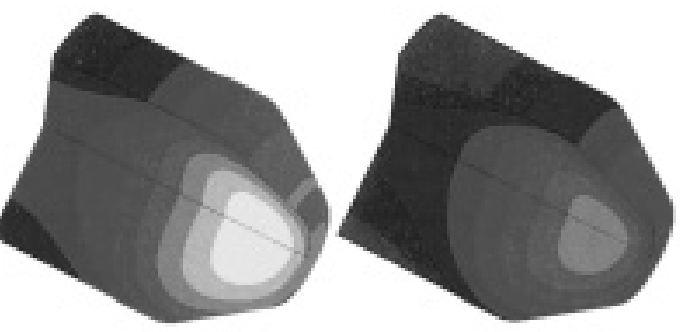

Pipe cooling system Jacket cooling system After oil cooling

Fig.14. Punch temperature distribution by FEM analysis by difference of cooling method.

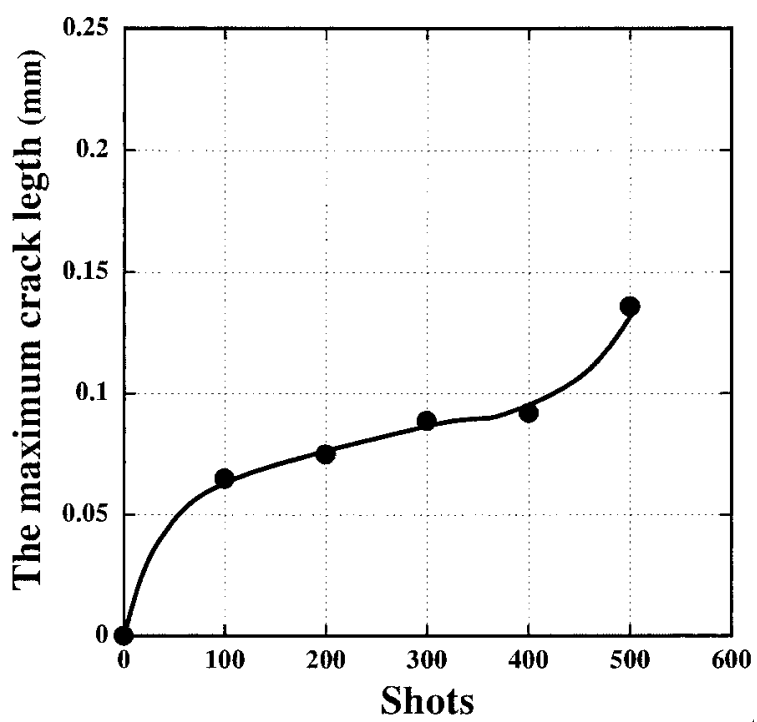

Fig.15. Punch temperature distribution when water-cooled.

パンチ温度の振幅は 銅パイプ式ノズル冷却法では $589 \mathrm{~K}$ ， ジャケット型の冷却法では $621 \mathrm{~K}$ となった .この温度振幅 が大きいほど, 熱応力起因によるヒートチェックを発生さ せることから，ジャケット型の冷却法の方がヒートチェッ クを発生させる傾向がやや高いことも確認された .

以上より,パンチの温度を下げるために金型の冷却を向 上させるプロセスを適用することは，温間鍛造における金 型寿命の改善に効果があることがわかる .

Fig.15に，初期鍛造時のパンチ表面の表面粗さ測定から 算出したヒートチェックの発生と光の成長を時系列にま とめた結果を示す．ヒートチェックは，鍛造初期である 100 ショット目から発生することか確認でき, 乥れ以降の 鍛造でさらにヒートチェックの深さが増大することが確
認できた .これは, 鍛造時のパンチ金型表面におけるヒー トチェック発生メカニズムを解明する重要な知見となる ことが期待される。

以上より,本試験法は, 温間鍛造時におけるパンチ金型 の摩耗,塑性流動, ヒートチェックといった金型損傷につ いて実機鍛造を模擬した条件で再現し，光れらの損傷を定 量的に調査することが可能であることが示された . また ， 金型材質を変化させて試験を行うことにより，乥れらの金 型損傷レベルを同時に比較することができ,最適な金型材 質を選択することを可能になった .

\section{5 .まとめ}

・本試験法は , 温間鍛造におけるパンチ金型の摩耗, 塑性 流動 ,ヒートチェックといった損傷を 2 工程鍛造により良 く再現し，パンチ摩耗量を測定することによって，パンチ 材質による定量的な摩耗損傷の評価が可能となった .

・高温圧縮降伏強度が高い鍛造金型材ほど, 塑性流動や摩 耗に対する抵抗が高いことから金型損傷レベルが小さく なることが確認でき, 型材の基礎特性を反映できる評価が 得られた 。

・パンチへの潤滑油吹き付け方法を従来の銅パイプ式ノズ ルからスライド式ジャケット型に変更した結果, パンチ温 度の冷却能力が向上し, 鍛造によるパンチ摩耗量を $64 \%$ も低減させることが可能となった .この結果は, FEM 解 析により裏付けできた .

・本試験法は, 鍛造時の冷却方法によるパンチの損傷の差 異 ,パンチ表面の粗さの測定から鍛造時のヒートチェック 生成から成長まで定量的に評価できることが可能となっ た。 
(文 献)

1) 小島久義, 藤川真一郎, 石原章: 塑性と加工, 43(2002), 495,331 .

2) 早川邦夫, 中村保,田中繁一:塑性と加工, 43(2002), $497,546$.

3) 松井宗久,田中利秋 , 土屋能成, 中西広吉 鈴木寿之 野 上芳和 鈴木敏孝:平成13年度塑性加工学会春季講演会 講演論文集，(2001）,73。

4) 土屋能成, 中西広吉, 田中利秋 松井宗久, 明石忠雄 鈴 木寿之 野上芳和: 平成13年度塑性加工学会春季講演会 講演論文集, (2001), 75.

5) 鈴木寿之 野上芳和 鈴木敏孝, 中西広吉, 土屋能成, 田 中利秋 松井宗久:平成13年度塑性加工学会春季講演会 講演論文集, (2001), 77 .

6) 田中利秋 , 土屋能成 松井宗久, 中西広吉 鈴木寿之 野 上芳和, 明石忠雄: 第52回塑性加工連合講演会講演論文 集, 259 .

7) 中西広吉 野々山史男; 澤村政敏,田野敦: 塑性と加工, 37(1996), 421,207. 